\title{
PNEUMOTHORAX RELATED TO MECHANICAL VENTILATION: SILENT ENEMY
}

Branislav Mojsic, Ana Mandras, Maja Sujica, Sladjana Vasiljevic

The Institute for Health Protection of Mother and Child of Serbia "Dr Vukan Cupic" Belgrade, Serbia

\author{
PNEUMOTORAKS UDRUŽEN SA MEHANIČKOM \\ VENTILACIJOM PLUĆA \\ Branislav Mojsić, Ana Mandraš, Maja Šujica, Slađana Vasiljević \\ Institut za zdravstvenu zaštitu majku i deteta Republike Srbije "dr Vukan Čupić”, Novi Beograd, Srbija
}

\begin{abstract}
Pneumothorax is well known and described complication in intensive care unit patients (ICU). Incidence of this complication is higher in patients with underlying pathology. As it can be occult, it is of the most importance to think of it in patients on mechanical ventilation. In this case report we well present ventilator-related pneumothorax in infant: clinical presentation, diagnosis and management
\end{abstract}

Keywords: pneumothorax, mechanical ventilation, pediatric patients

\section{INTRODUCTION}

Pneumothorax is well known and described complication in intensive care unit patients (ICU). It can be classified as spontaneous, traumatic or iatrogenic. Iatrogenic pneumothorax has been reported in up to $3 \%$ of adult patients admitted in ICU., ${ }^{1,2}$ Estimations were made that the incidence in mechanically ventilated patients is $4 \%-15 \%{ }^{3,4}$ Pneumothorax is potentially lethal complication and if not recognized and treated, it can progress to tension pneumothorax and increase morbidity and mortality of ICU patients.

\section{CASE REPORT}

A 42 days old male infant, TM 3,8kg, with postnatal made diagnosis of Truncus arteriosus communis, ventricular and atrial septal defect and interrupted aortic arch was admitted to pediatric cardiac intensive care unit after complete correction of congenital heart defect. Previously he was operated and had devided colostomas. He was treated for sepsis and other nosocomial infections and had one episode of rightsided pneumothorax. From the day he was born, he was on mechanical ventilation, never took a breath

\section{SAŽETAK}

Pneumotoraks je dobro poznata komplikacija kod bolesnika u jedinicama intenzivnog lečenja. Incidenca ove komplikacije je veća kod bolesnika na mehaničkoj ventilaciji. Pneumotoraks može biti klinički teško prepoznatljiv u početku, ali veoma je važno misliti na njega kod bolesnika na mehaničkoj ventilaciji. Prikazaćemo slučaj deteta sa pneumotoraksom udruženim sa mehaničkom ventilacijom pluća, kliničku slku, dijagnozu i terapijski pristup .

Ključne reči: pneumotoraks, mehanička ventilacija, pedijatrjski bolesnici

on his own. After the operation his sternum stayed opened as a standard procedure, to relieve pressure on the heart. Measured pressure in pulomary artery was $70 \%$ of systolic pressure. Initial ventilator settings were: $\mathrm{PCV}, \mathrm{FiO}_{2} 85 \%$, Pinsp 23-25cmH2O, PEEP 5-6cm H2O, Tinsp 0,7s, RR 26/ $\mathrm{min}$, achieved Vt $8 \mathrm{ml} / \mathrm{kg}$. The goal was to achieve $\mathrm{PaO}_{2}>$ $80 \mathrm{mmHg}$, normocarbia and $\mathrm{pH} 7,45-7,50$. He was countinously sedated with midasolam, analgesia was provided with countinous infusion of fentanyl and muscle relaxation achieved by intermittent boluses of rocuronium. Inotropic support and afterload reduction was made by milrinione, diuresis was regulated by countinous infusion of furosemide. On the first postoperative day sternum was closed without impact on hemodynamics and lung function.

The child was stable in following days with average TA $86 / 33 / 51 \mathrm{mmHg}$, HR 130/min, CVP 11-12cm H2O , diuresis $\geq 1 \mathrm{ml} / \mathrm{kg} / \mathrm{h}$,_SpO2 98\%, FiO2 80\%, blood gas analysis (BGA) pH 7,51, $\mathrm{PaO} 290 \mathrm{mmHg}, \mathrm{PaCO} 235$ $\mathrm{mmHg}, \mathrm{HCO} 3$ 28, BE 4,8, Hgb 12 g/dl, SaO2 98\%. On auscultation of lungs one could hear equal breathing sounds on both sides with lot of crackles. In the evening on the third postoperative day sudden desaturation 


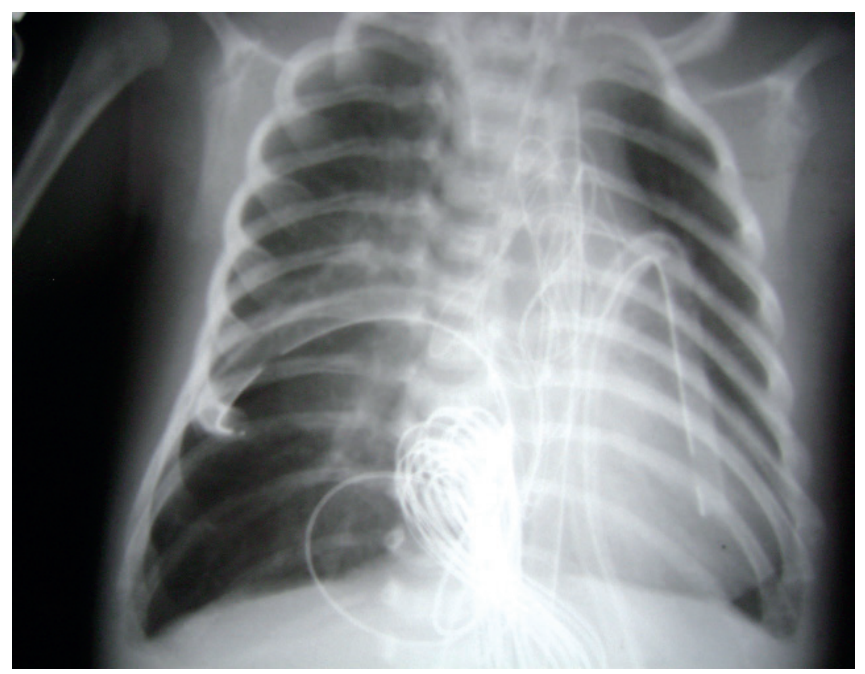

Picture 1. First postoperative day

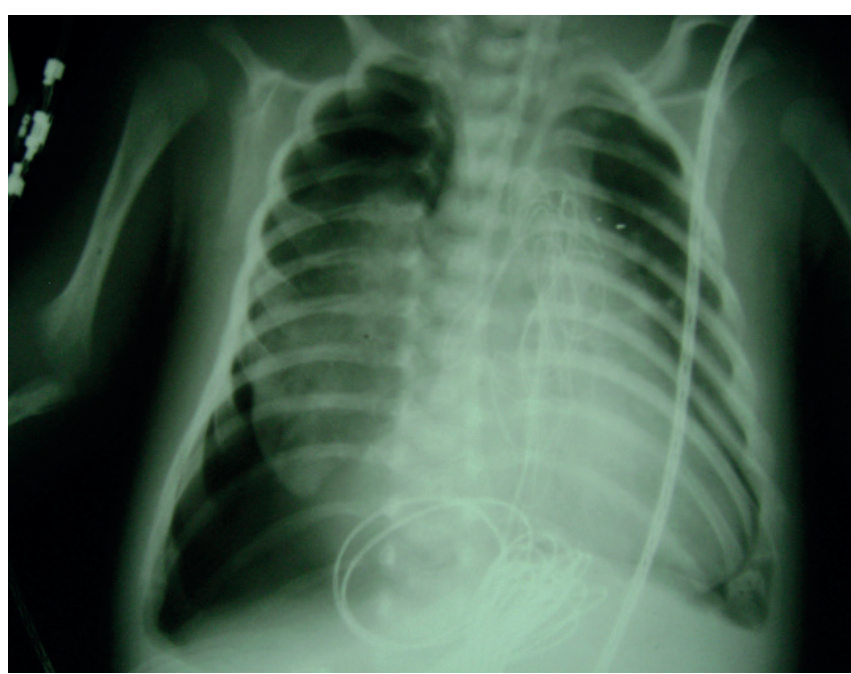

Picture 2: Third postoprative day : pneumothorax on right side, more than $20 \%$ of cavity

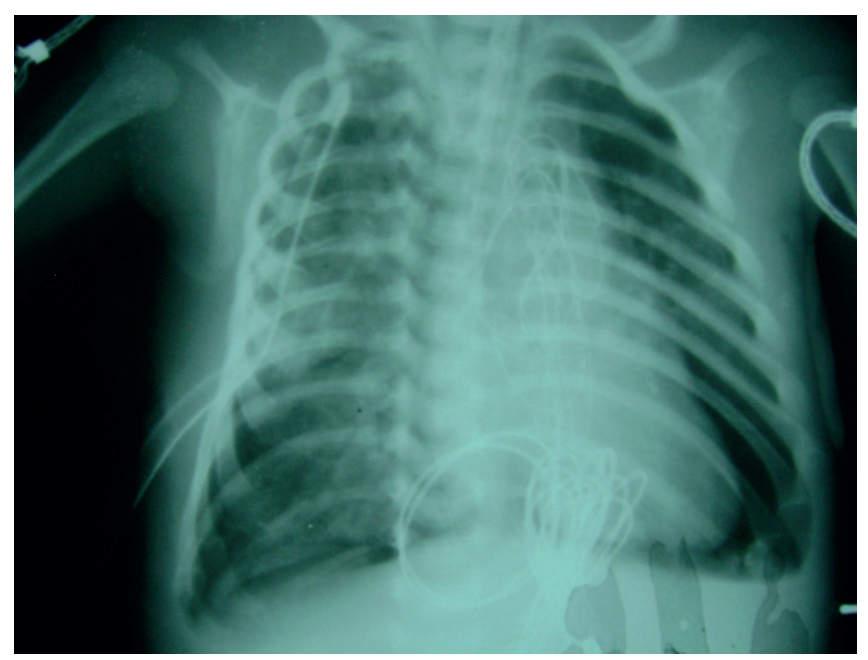

Picture 3: Reexpansion of the lung after 12 hours

occurs with $\mathrm{SpO}_{2} 80 \%, \mathrm{FiO}_{2} 80 \%$. Desaturation was followed by increase in blood and central venous pressure - TA 95/36/56 mmHg, HR 156/min , CVP 14-15 cmH2O. BGA showed respiratory acidosis $(\mathrm{pH} 7,26, \mathrm{PaO} 251$
mmHg, PaCO2 83mmHg, HCO3 26,3, BE 5,3, SaO2 77\%, Hgb $11,8 \mathrm{mg} / \mathrm{dl}$ ), auscultation of lungs confirmed slightly decreased, symmetrical breathing sounds. On manual ventilation with $100 \%$ oxygen lungs were stiff, bolus of fentanyl was given, and after aspiration mucus plug was evacuated. The episode resolved in 30 minutes, and child was stable again but maximal measured saturation on FiO2 100\% oxygen was 93\%. This made attending ICU doctor unsatisfied and alert to reassaess after 30 minutes again. This time on auscultation breathing sound was diminished on right side. Radiography was made and diagnosis of pneumothorax was obvious. Complete right lung was collapsed leaving more than $20 \%$ of cavity filled with air. Immediate chest tube was inserted

Staisfactory reexpansion was achieved after 12 hours, with significant improvement in oxygenation, BGA : SpO2 98\%, FiO2 60\%, pH 7,53, PaO2 110 mmHg, PaCO2 36mmHg, HCO3 30, BE 6,8, SaO2 99\%, Hgb 11,2 mg/dl.

\section{DISCUSSION}

In critical illness, pneumothoraces may be difficult to diagnose if they have atypical presentation and are complicated by underlying disease in unconscious patients. . $^{5,6}$ Unrecognized pneumothorax in patients on mechanical ventilation could rapidly progress to tension pneumothorax which is more common in this patient population, occurring in $30 \%-97 \%$ of all pneumothoraces. ${ }^{7-9}$. If barotaruma is complication of mechanical ventilation, the mortailty rates are high, ranging from $46 \%-77 \% .^{4,7-9}$. Having this data in mind, pneumothorax should not be an issue in patients on mechanical ventilation. In another words, awareness of this lethal complication should be present at all times especially in those who have underlying disease, since barotrauma has been more related to changes in lung parenchyma and lung compliance than ventilator settings alone. ${ }^{10}$

The diagnosis of pneumothorax includes patient's history, examination, and radiological investigations. In our patient, data of prolonged mechanical ventilation, sepsis, nosocomial infections, recent cardiopulmonal bypass with its` effect on lungs and history of previous pneumothorax alerted us to be more carefull. Therefore, we applied, as described above, lung protective strategy during mechanical ventilation and performed repeated auscultation of the chest. Often reassessment of this child and high level of awareness of pneumothorax possibility made diagnosis prompt. Once suspected, pneumothorax conformation with chest $\mathrm{X}$ ray should be made, since it's reliable, cheap and easy to perform diagnostic tool. According to British Thoracic Society : "Standard practice is to place a chest tube for any pneumothorax occurring during mechanical ventilation, due to the risk of positive pressure expanding the pneumothorax into a tension pneumothorax" implying that size of pneumothorax is not determinant of management itself. ${ }^{11}$ 


\section{CONCLUSION}

As in all other diseases and conditions we deal with in everyday practice, prevention of pneumothorax comes in the first place. Applying lung protective strategies decrease incidence of pneumothorax but doesn't exclude one, and should be always applied according to recommendations. Besides this, recognition of risk factors (e.g. underlying pathology) is important also in reducing possibility of this serious complication. In pediatric population, risk factors related to pneumothorax are: extremely low birth babies (ELBW), premature babies, neonates delivered by cesarian section, neonates with RDS, aspiration of meconium syndrome, chlidren with underlynig lung pathology,cardiothoracic procedures and prolonged mechanical ventilation and previous episodes of pneumothorax. There is no definite consensus how to treat pneumothorax in conscious patients, especially one that is $<15 \%$ of thorax cavity, but there has definite recommendation has been made to decompress pneumothoraces in patients on mechanical ventilation.

\section{REFERENCES:}

1. Baumann MH. Pneumothorax. Semin Respir Cric Care Med 2001;22:647-656

2. De Lassence A, Tismit JF, Tafflet M, Azoulay E, Jamali S, Vinent F, Cohen Y, Garrouste-Org, Albert C, Dreyfuss D. Pneumothorax in intensive care unit: Incidence, risk factors and outcome.Anestehsiology 2006;104:5-13
3. Strange C.Pleural complications in intensive care unit. Clin Chest Med 1999;20:317-327

4. Zwillich CW, Pierson DJ, Creagh CE, Sutton FD,Schatz E, PettyTL.Complications of assisted ventilation. A prospective study of 354 consecutive episodes. Am J Med 1974;57:161-170

5. Tocino IM, Miller MH, Fairfax WR.Distribution of pneumothorax in supine and semirecumbent critically ill adult.AJR Am J Roentgenol 1985;144:901-905

6. Rankine JJ, Thomas AN, Fluechter D.Diagnosis of pneumothorax in critically ill adults.Postgrad Med J 2000;76:399-404

7. Rohlfing BM, Webb WR, Schlobohm RM.Ventilator related extra alveolar air in adults. Radiology 1976;121:25-31

8. Woodring JH.Pulmonary interstitial emphysema in the adult respiratory distress syndrome. Crit Care Med 1985;13:786-791

9. Miller MP, Sagz M. Pressure characteristics of mechanical ventilation and incidence of pneumothorax before and after the implementation of protective lung strategies in the management of pediatric patients with severe ARDS. Chest 2008; 134:969-973

10. Boussari M, Thierry G, Jaber S,Roudot-Thoraval F, Lemaire F, Brochard L. Relationship between ventilator settings and barotraumas in the acute respiratory distress syndrome. Intensive Care Med 2002;28:406-413

11. www.BTS guidelines 2010 


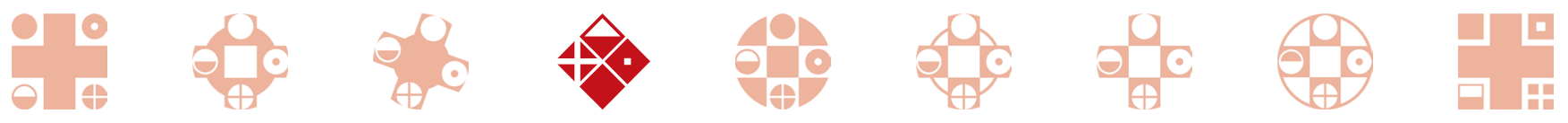

